\title{
離れた長方形壁のつくる内角の直角知覚に関する 実験的研究
}

（その 3 ・堅長壁及び横長壁が $3 \mathrm{~m}$ 離れた場合）

正会員福 原 昌 明*

2 枚の長方形壁がL字形に交わって地上飞直立する場 合，及びそれがたがいに $1 \mathrm{~m}$ 離れた場合の内角の直角知 覚については，それがやや鋭角，つまり，約 85 度のと き直角泟光ることがわかった。

その際, 前記雨実験の間には，その内角の直角知覚に

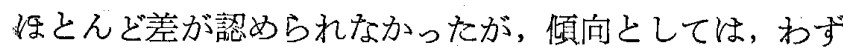
かながら後者の方が鋭角の度合が増大しているように思 われる。

以上のことから，その 2 枚の壁模型が更㨬くに離れ た場合，その内角の直角知覚もまた何らかの变化がある ものと考えられるので，それがどのようと変化するかを 確めるために，上記 2 枚の壁模型の間隔が $3 \mathrm{~m}$ 離れた場 合について, 前実験と同様な方法で, 堅長壁と横長壁の 汕方をあわせて実験を行った。

装置は前実験に用いたものを使用したが，第 1 図のよ

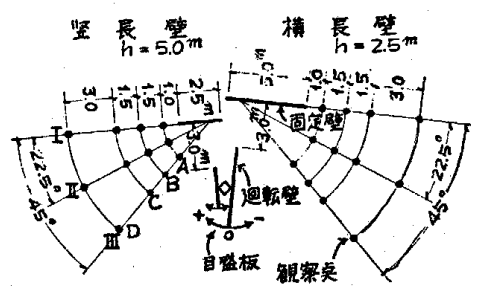

第 1 図 実験装置及び観察位置

うに，廻転壁が固定壁と直交する場合にたがいの間隔を $3 \mathrm{~m}$ 離して直立させ, 竪長壁, 横長壁共それぞれ 12 䇢 所の観察点を，距離と偏角飞分けて配置した。

実験方法は前回同様，極限法により 20 名の被験 者に ついて, + $\rightarrow-$ - 3 回, $-\rightarrow+を 3$ 回, 日常環境下で, 観察順序，実験順序が不規則になるように行った。

結果は第 1 表及び第 2 図の通り，やはり鋭角のとき直 角知覚を生じるが，その度合は一般竪長壁の方が大き い。これは，横長壁にくらべて直角を判断する手がかり がより少いことが原因であるう。前実験とくらべた場合 壁模型の間隔が離れると従って，その鋭角の度合も次第 灶大きくなてゆく傾向がみ元る。

観察距離によるちがいは，距離が遠くなると従って鋭 角の度合が減少する。特に堅長壁の場合飞著しい。この

* 熊本大学講師
第 1 表 実験結果の諸平均值

㹂 長 壁

単位 度

\begin{tabular}{|c|c|c|c|c|c|}
\hline & A 群 & B 群 & C 群 & D 群 & 各群平均 \\
\hline I 群 & -8.57 & -8.26 & -6.78 & -6.00 & -7.40 \\
\hline II 群 & -10.00 & -8.36 & -7.80 & -5.25 & -7.85 \\
\hline III 群 & -9.67 & -9.58 & -7.46 & -4.91 & -7.91 \\
\hline 各群平均 & -9.41 & -8.73 & -7.35 & -5.39 & -7.72 \\
\hline
\end{tabular}

横 長 壁

\begin{tabular}{|c|c|c|c|c|c|}
\hline & A 群 & B 群 & C 群 & $\mathrm{D}$ 群 & 各群平均 \\
\hline I 群 & -5.33 & -4.81 & -4.86 & -4.18 & -4.79 \\
\hline II 群 & -8.37 & -7.80 & -7.68 & -5.95 & -7.45 \\
\hline III 群 & -9.06 & -7.23 & -6.39 & -5.59 & -7.07 \\
\hline 各群平均 & -7.59 & -6.61 & -6.31 & -5.24 & -6.44 \\
\hline
\end{tabular}

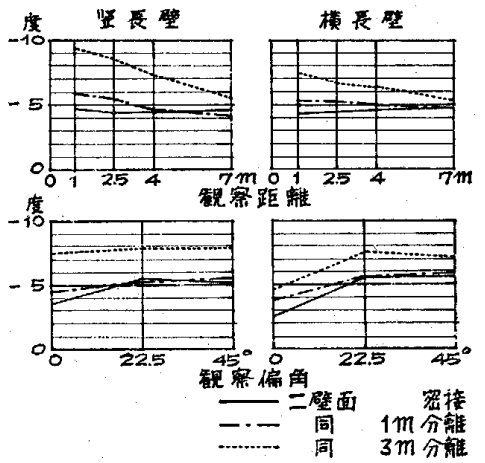

第 2 図 直角知覚の変化

場合，距離が近くなると壁面の上下左右を同時に視野に 収めるのが困難になり，遠ざかるにつれて見やすくなる ことにもよるるのと思われる。事実, 壁模型の間隔が離 れるに従って距離䏠るらがいが大きくなることも，そ れを示唆している。

観察偏角によるちがいは，㹂長垶ではほとんどなくな るが，横長壁では壁模型の間隔が離れても，前同様，I 群とII，正群の差がかなり大きいという傾向は変らな W。

全体的にみて，2 枚の長方形壁が離れるに従ってその 内角の直角知覚はより鋭角となり，その場合，観察距離 が遠いほど真の直角に近い。しかし, 直角知覚の上限, 下限の問題, 更に, 対象飞よってそれが如何に変化する かは残された問題であるう。 